\title{
Erratum: Selenium removal from petroleum refinery wastewater using an electrocoagulation technique
}

\author{
Mohammad Mahdi Emamjomeh \\ Social Determinants of Health Research Center, Research Institute for Prevention of Non-Communicable Diseases, Qazvin University of Medical Sciences, Qazvin, Iran
}

A R T I C L E I N F O

Editor: Navid B Saleh

Dear Editor,

The current letter is going to have discussion on the paper published in your Journal as titled: "Selenium removal from petroleum refinery wastewater using an electrocoagulation technique" Journal of Journal of Hazardous Materials 364 (2019) 78-81. Written by: Henrik K. Hansena, Sebastián Franco Peñaa, Claudia Gutiérreza, Andrea Lazoa, Pamela Lazob, Lisbeth M. Ottosenc.

The authors noted that the initial concentration of selenium was reported to be $0.30 \mathrm{mg} \mathrm{L}^{-1}$ in the wastewater. Energy consumption as a function of EC treatment time was studied for a current density of 153.4 $\mathrm{A} \mathrm{m}^{-2}$. The used treatment times were $1,2,4$ and $6 \mathrm{~h}$ when the current densities of 76.7 and $153.4 \mathrm{~A} \mathrm{~m}^{-2}$ were considered (Hansena et al., 2019). The increase in the treatment time also produces a rise in the used energy per $\mathrm{mg}$ of removed selenium. The used operational conditions together the corrected results of the EC experiments are reported in Tables 1 and 2. In this work, when a fixed current of $1.68 \mathrm{~A}$ was applied, the values of voltage in the cell were $3.46,3.70,3.90$ and $3.18 \mathrm{~V}$ for treatment times of $60,120,240$, and $360 \mathrm{~min}$, respectively. In the case of a current of $0.84 \mathrm{~A}$, the voltage drop across the cell just reached the minimum required and therefore only low Se removal was observed (Hansena et al., 2019). This work had been well done and the quality of the published paper is very good. But needs some clarification mentioned in some of the calculated values as an erratum in Tables 3 and 4. It was better to show that how energy consumption has been determined in the text (Xu et al., 2018; Emamjomeh, 2017). Although it is clear that methodology of calculation of the energy consumption is
Table 1

Electrical data, residual selenium concentration, energy consumption and $\mathrm{pH}$ in the EC experiments with a current density of $153.4 \mathrm{~A} \mathrm{~m}^{-2}(1.68 \mathrm{~A})$.

\begin{tabular}{llllll}
\hline Time & $\mathrm{min}$ & 60 & 120 & 240 & 360 \\
Residual selenium & $\mathrm{mg} \mathrm{L}^{-1}$ & 0.20 & 0.10 & 0.05 & 0.03 \\
\hline Initial pH & - & 5.0 & 5.0 & 5.0 & 5.0 \\
Final pH & - & 6.7 & 6.9 & 7.9 & 8.0 \\
Voltage & $\mathrm{V}$ & 3.46 & 3.7 & 3.9 & 3.18 \\
Power & $\mathrm{W}$ & 5.88 & 6.22 & 6.59 & 5.37 \\
Energy & $\mathrm{Wh}$ & 5.88 & 12.43 & 26.34 & 32.21 \\
Energy consumption to removed Se & $\mathrm{Wh} \mathrm{mgSe}$ & 58 & $\mathbf{6 2}$ & 105 & 119 \\
& & & & &
\end{tabular}

Table 2

Electrical data, residual selenium concentration, energy consumption and $\mathrm{pH}$ in the EC experiments with a treatment time of $240 \mathrm{~min}$.

\begin{tabular}{llll}
\hline $\begin{array}{lll}\text { Current density } \\
\text { Current intensity }\end{array}$ & $\mathrm{A} \mathrm{m}^{-2}$ & 76.7 & $\begin{array}{l}153.4 \\
1.68\end{array}$ \\
\hline Residual selenium & $\mathrm{A}$ & 0.84 & 0.05 \\
Initial pH & $\mathrm{mg} \mathrm{L}^{-1}$ & 0.15 & 0.0 \\
Final pH & - & 5.0 & 7.9 \\
Voltage & - & 6.7 & 3.9 \\
Power & $\mathrm{V}$ & 2.8 & 6.59 \\
Energy & $\mathrm{W}$ & 2.35 & 26.34 \\
Energy consumption to removed Se & $\mathrm{Wh}$ & 9.41 & 105 \\
\hline
\end{tabular}

E-mail address: m_emamjomeh@yahoo.com. 
Table 3

Erratum: Electrical data, residual selenium concentration, energy consumption and $\mathrm{pH}$ in the EC experiments with a current density of $153.4 \mathrm{~A} \mathrm{~m}^{-2}(1.68 \mathrm{~A})$.

\begin{tabular}{|c|c|c|c|c|c|}
\hline Time & $\min$ & 60 & 120 & 240 & 360 \\
\hline Residual selenium & $\mathrm{mg} \mathrm{L}^{-1}$ & 0.20 & 0.10 & 0.05 & 0.03 \\
\hline Initial $\mathrm{pH}$ & - & 5.0 & 5.0 & 5.0 & 5.0 \\
\hline Final pH & - & 6.7 & 6.9 & 7.9 & 8.0 \\
\hline Voltage & $\mathrm{V}$ & 3.5 & 3.7 & 3.9 & 3.2 \\
\hline Power & W & 5.88 & 6.22 & 6.59 & 5.37 \\
\hline Energy & Wh & 5.88 & 12.43 & 26.34 & 32.21 \\
\hline Energy consumption & Wh $\mathrm{mgSe}^{-1}$ & 58 & & 105 & 119 \\
\hline
\end{tabular}

Table 4

Erratum: Electrical data, residual selenium concentration, energy consumption and $\mathrm{pH}$ in the EC experiments with a treatment time of $240 \mathrm{~min}$.

\begin{tabular}{llll}
\hline $\begin{array}{l}\text { Current density } \\
\text { Current intensity }\end{array}$ & $\mathrm{A} \mathrm{m}^{-2}$ & 76.7 & 153.4 \\
& $\mathrm{~A}$ & 0.84 & 1.68 \\
\hline Residual selenium & $\mathrm{mg} \mathrm{L}^{-1}$ & 0.15 & 0.05 \\
Initial pH & - & 5.0 & 5.0 \\
Final pH & - & 6.7 & 7.9 \\
Voltage & $\mathrm{V}$ & 2.8 & 3.9 \\
Power & $\mathrm{W}$ & 2.35 & 6.59 \\
Energy & $\mathrm{Wh}$ & 9.41 & 26.34 \\
Energy consumption & $\mathrm{Wh} \mathrm{mgSe}{ }^{-1}$ & & 105 \\
\hline
\end{tabular}

based on the energy rate and the removed selenium concentration. So the energy consumption can be rearranged to "energy consumption to removed Se" in Tables 1 and 2. There are also two invalid values on row of energy consumption in Tables 3 and 4 . The values must be corrected from 79 to $62 \mathrm{Wh} \mathrm{mgSe}{ }^{-1}$ and from 135 to $62.7 \mathrm{Wh} \mathrm{mgSe}^{-1}$ as is shown in Tables 1 and 2, respectively. Based on the results shown in Table 1, the selenium removed concentration was $0.2 \mathrm{mg} \mathrm{L}^{-1}$ when the electrolysis time was applied $120 \mathrm{~min}$ for a current value of $1.68 \mathrm{~A}$. Also, the selenium removed concentration was calculated $0.15 \mathrm{mg} \mathrm{L}^{-1}$ when the current rate and treatment time were reported to be $0.84 \mathrm{~A}$ and $240 \mathrm{~min}$, respectively (shown in Table 2). The following correction comments (shown in Tables 1 and 2) need to be considered to other paper readers when these comments are suggested for further processing as an erratum on this published paper.

\section{References}

Emamjomeh, M.M., 2017. Erratum: defluoridation of drinking water using a new flow column electrocoagulation reactor (FCER) - Experimental, statistical, and economic approach. J. Environ. Manage. 201, 315.

Hansena, H.K., Peñaa, S.F., Gutiérreza, C., Lazoa, A., Lazob, P., 2019. Lisbeth M.

Ottosenc. Selenium removal from petroleum refinery wastewater using an electrocoagulation technique. J. Hazard. Mater. 364, 78-81.

Xu, L., Xu, X., Cao, G., Liu, S., Duan, Z., Song, S., Song, M., 2018, M. Zhang. Optimization and assessment of Fe-electrocoagulation for the removal of potentially toxic metals from real smelting wastewater. J. Environ. Manage. 218, 129-138. 